\title{
"The Worst Divorce Case that Ever Happened": The New York Times Women's Caucus and Workplace Feminism
}

\author{
Marama Whyte (D)
}

In 1974, women at the New York Times made national headlines when they filed a class-action sex discrimination lawsuit. The drama of the court case, however, has overshadowed the formation of the Times Women's Caucus two years prior, in 1972. A focus on the Caucus, the daily labor its members undertook in the years before and after filing suit, and the behind-the-scenes negotiation of internal office politics reveals the years-long process of consciousness raising and workplace organizing required to undertake a lawsuit in this novel legal area. Activist newswomen operated with unique restrictions and necessarily distanced themselves from the feminist movement, while quietly advocating for feminist goals. Caucus members drew from the feminist, labor, and union movements strategically rather than ideologically, and laid the foundation for substantial shifts in women's participation and representation in the mainstream media.

On February 1, 1972, a small group of women from the New York Times news department quietly gathered at Act One, a white-tableclothed restaurant at the top of One Times Square. ${ }^{1}$ The building-now famous for its huge billboards and electronic news ticker-had once served as the New York Times headquarters. By 1972, the paper had moved around the corner to new premises, and Times employees rarely returned to the once-favored restaurant. It was a safe place to meet. "Things are a-foot and they ain't a-foot at the New York Times," arts columnist Grace Glueck proclaimed to the group. She referenced ongoing negotiations by women at Newsweek, who had charged their employer with sex discrimination on March 16, 1970, in a headline-grabbing press conference timed to coincide with a Newsweek cover on the women's movement proclaiming "Women in Revolt." ${ }^{2}$ Further rumblings emanated from women at Time Inc., CBS, and the Associated Press, among other media outlets. Energized by Glueck's passion and frustrated by their own experiences of discrimination and sex segregation, the group agreed to draft a "manifesto" to management on behalf of frustrated women at the Times. ${ }^{3}$

This lunchtime decision launched the Times newswomen into an intense six-year employment rights campaign. During the 1970s, the New York Times Women's Caucus, as they eventually christened themselves, tried out a range of strategies, including negotiating with

An early version of this article was presented at Binghamton University's Upstate New York Modern U.S. History Workshop and the 2018 American Journalism Historians Association Conference, and I thank the participants for their comments, especially Leigh Ann Wheeler and Maurine H. Beasley. Thank you to Chris Hilliard, Hollie Pich, Pamela Maddock, Thomas Adams, and Thomas Sugrue for their generous feedback, and especially to Mike McDonnell and Clare Corbould. Finally, thank you to Sarah Phillips and the anonymous reviewers for their helpful suggestions, and to Sarah and the editorial assistants for their editorial guidance.

${ }^{1}$ Nan Robertson, The Girls in the Balcony: Women, Men, and the New York Times (New York, 1992), 142.

${ }^{2}$ For a full account of the Newsweek discrimination complaint, see Lynn Povich, The Good Girls Revolt: How the Women of Newsweek Sued Their Bosses and Changed the Workplace (New York, 2012).

${ }^{3}$ Betsy Wade, interview by Mary Marshall Clark, 1992-1993, transcript, Washington Press Club Foundation Women in Journalism Oral History Project, Washington, DC.

(C) The Author(s), 2020. Published by Cambridge University Press 
management, consciousness raising in their workplace, starting an internal newsletter, hiring lawyers, working with their union, and deploying different legal and legislative mechanisms. ${ }^{4}$ In 1974, they filed a sex discrimination complaint with the Equal Employment Opportunity Commission (EEOC) under Title VII of the Civil Rights Act of 1964, which made it unlawful for any employer to discriminate or segregate on the basis of "[an] individual's race, color, religion, sex, or national origin." Granted permission to file suit as a class in 1977, they were preparing to go to trial when they reached a last-minute settlement with the Times in 1978, which set out goals and timetables for hiring women over the next five years. Their work did not end there; well into the 1980s, Caucus members monitored this agreement and continued to negotiate with the Times.

A close study of the early activist labor that Caucus members undertook before filing the 1974 lawsuit uncovers the feminist activism that took place on the ground in U.S. newsrooms and news institutions in the 1970s. ${ }^{6}$ I reconstruct their work through a close analysis of Caucus records, New York Times company records, and printed sources including memoirs, oral history interview transcripts, and newspaper articles. Newswomen involved in these campaigns were unsure of exactly which tactics would inspire the changes they sought or would attract the greatest number of Times women, and so they tested a variety of strategies. This resulted in a highly experimental, improvisational, and adaptive approach that varied depending on the immediate circumstances and the background of individual participants. More specifically, the Caucus members' chosen strategies were the product of their specific work in the media, their reporting on the feminist movement, and their background in labor organizing. Here we gain a picture of the workplace politics of undertaking a sex discrimination suit against an employer where the plaintiffs continued to work. As the Times's own lawyers described, this lawsuit would be "the worst divorce case that ever happened" because "these people who get divorced will then have to live with each other afterward. How are they going to work together? How are they going to look at each other? How will they get a newspaper out?"7

This story is therefore a study of the media primarily as a site of employment, rather than a site of protest. $^{8}$ The media exercises an outsized role and influence in determining how the nation-and the world-form understandings and beliefs. In addition to the Caucus, newswomen organized at the Washington Post, Time Inc. (which operated Time, Life, Fortune, and Sports Illustrated), Newsday, the Detroit Sun, the Baltimore Evening Sun, Reader's Digest, NBC, the Associated Press, and numerous other publications around the country. ${ }^{9}$ Historians need to understand how the nature of their media work shaped the activism the

\footnotetext{
${ }^{4}$ The Caucus has received occasional interest from historians, in part due to Caucus member Nan Robertson's memoir, The Girls in the Balcony. For an additional brief history, see Linda Steiner, “The New York Times Women's Caucus, 1972-Present," in Women's Press Organizations, 1881-1999, ed. Elizabeth V. Burt (Westport, CT, 2000), 164-70. The most substantial analysis of the Caucus is found in chapter 2 of Katherine Turk, Equality on Trial: Gender and Rights in the Modern American Workplace (Philadelphia, 2016).

${ }^{5}$ Title VII of the Civil Rights Act of 1964, 42 U.S.C., sec. 2000e (1970).

${ }^{6} \mathrm{I}$ am inspired here by Joanne Meyerowitz's suggestion to expand women's and labor histories through a focus on "close historical case studies of economic change in specific communities and female dominated occupations." The media in the 1970s was not a female-dominated profession generally, but it was a highly sex-segregated one where newswomen were restricted to particular news beats or subsections. Joanne Meyerowitz, "Introduction: Women and Gender in Postwar America, 1946-1960," in Not June Cleaver: Women and Gender in Postwar America, 1945-1960, ed. Joanne Meyerowitz (Philadelphia, 1994), 1-18, here 5.

${ }^{7}$ Robertson, The Girls in the Balcony, 202.

${ }^{8}$ Turk argues that the Caucus had more in common with the sex discrimination cases that played out at Ford Motor Company, General Electric Corporation, and American Telephone and Telegraph, for example, than with feminist sit-ins or other media-centric protests. While not disputing Turk's claim, I reposition the Caucus within its media context. In comparison, Turk's work analyzes the development of the "sex" clause in Title VII, and is concerned with the breadth of interpretations across professions and decades. Turk, Equality on Trial, 39-40.

${ }^{9}$ Povich, The Good Girls Revolt, 1-2, 9.
} 
Caucus undertook, alongside the opportunities and restrictions that their specific workplace context generated. For example, Caucus members occupied a unique position to shape public consciousness through their reporting. Simultaneously, concerns over "objectivity" in their reporting meant their interactions with the feminist movement were often more restricted than professional women in other industries. ${ }^{10}$

The majority of scholarship on the feminist movement has, understandably, focused on those women who self-identified as feminists or participated in activism coordinated by feminist organizations. But the Caucus asks us to question how scholars incorporate, or understand, those women who undertook feminist actions while actively not identifying as feminists. ${ }^{11}$ I position the Caucus as both a professional women's workplace organization, and as a window onto the historical politics of gender and the media. The actions of the Caucus not only broaden our understanding of how feminist activism unfolded in the 1970s, but the newswomen's efforts also illuminate the complex and undulating relationship between the feminist movement and mass media. ${ }^{12}$

\section{Newswomen and Labor Feminism}

The majority of scholarship on media Title VII lawsuits has remained within journalism and media studies, concerned with the specifics of journalism as a profession. ${ }^{13}$ But we now need to connect the grassroots activist campaigns undertaken by newswomen with the vibrant campaigns that feminists of all ideologies undertook around mass media during the "second wave." ${ }^{14}$ Newswomen were not isolated from the feminist movement; many of those involved

\footnotetext{
${ }^{10}$ The struggle to remain "objective" was not entirely unique to journalism and was shared, for example, by the women who taught women's studies programs at universities and colleges in the 1960s and 1970s, as well as women lawyers who worked on issues of sex and gender, who were often under similar pressure to prove their objectivity to ensure their professional recognition. For the "double consciousness" of being "a woman and a professional,” see Nancy F. Cott, The Grounding of Modern Feminism (New Haven, CT, 1987), ch. 7. On gendered office work, see Katherine Turk, "Labor's Pink-Collar Aristocracy: The National Secretaries Association's Encounters with Feminism in the Age of Automation," Labor: Studies in Working-Class Histories of the Americas 11, no. 2 (Summer 2014): 85-109.

${ }^{11} \mathrm{I}$ am building here on work by A. Finn Enke and Stephanie Gilmore. Enke argues that in the 1970s, many women "enacted feminism through a dazzling array of action that was spontaneous, unattached to named organizations.” A. Finn Enke, Finding the Movement: Sexuality, Contested Space, and Feminist Activism (Durham, NC, 2007), 2-7. Gilmore contends that women involved in grassroots organizing comprised "small groups dedicated to changing status quo, not in response to a call from national leaders but from the needs of people around them in their day-to-day lives." Stephanie Gilmore, Groundswell: Grassroots Feminist Activism in Postwar America (New York, 2013), 5-7.

${ }^{12}$ In Media Nation, Bruce J. Schulman and Julian E. Zelizer argue that only recently have scholars taken up the challenge to "integrate mass media ... into the master narratives of modern American political development," yet their edited collection did not engage with the feminist movement, despite it being one of the most important political movements of the twentieth century and one which was explicitly interested in mass media's role within society. Bruce J. Schulman and Julian E. Zelizer, "Introduction," in Media Nation: The Political History of News in Modern America, eds. Bruce J. Schulman and Julian E. Zelizer (Philadelphia, 2017), 1-9, here 4.

${ }^{13}$ For Title VII lawsuits in journalism history and media studies, see Maurine H. Beasley and Sheila J. Gibbons, Taking Their Place: A Documentary History of Women and Journalism, 2nd ed. (State College, PA, 2003); Carolyn M. Byerly, "Feminist Interventions in Newsrooms," in Women and Media: International Perspectives, eds. Karen Ross and Carolyn M. Byerly (Malden, MA, 2004), 109-31; and Deborah Chambers, Linda Steiner, and Carole Fleming, Women and Journalism (New York, 2004). For the legal history of the media and Title VII, see Sha-Shana Crichton, "The Incomplete Revolution: Women Journalists-50 Years After Title VII of the Civil Rights Act of 1964, We've Come a Long Way Baby, But Are We There Yet?," Howard Law Journal 58, no. 1 (Fall 2014): 49-112.

${ }^{14}$ The use of the media by feminist activists has been detailed comprehensively in Patricia Bradley, Mass Media and the Shaping of American Feminism, 1963-1975 (Jackson, MS, 2003). See also Bernadette Barker-Plummer, "News as a Political Resource: Media Strategies and Political Identity in the U.S. Women's Movement, 1966-
} 
in workplace activism report being politicized through their reporting on the feminist movement, such as Newsweek writer Lynn Povich, who credited her coverage of the gay rights and women's rights movements for "expanding [her] worldview." ${ }^{15}$ Covering the burgeoning feminist movement was a balancing act for many newswomen employed at mainstream print publications. As Times Caucus leader Betsy Wade recalled, "You practically had to go in and take an oath that you didn't believe in the women's movement in order to cover the women's movement." ${ }^{\prime 6}$ Peggy Simpson, later a plaintiff in a Title VII lawsuit at the Associated Press, described a "friction" between newswomen and the "virtually all-male management" who "thought the movement was a joking matter."17 Often the same newswomen who undertook employment rights campaigns also reported on the feminist movement. These women shaped national conversations and understandings of feminism, even if their reporting was filtered through the sexist lens often imposed by traditional news media. ${ }^{18}$ Despite their small numbers, the presence of even one woman in a newsroom who incorporated her new feminist consciousness into her reporting was a seismic shift within a profession which-through its preference for a white, male outlook—contributed to the "symbolic annihilation" of women in mass media. ${ }^{19}$ The Caucus made this connection almost immediately and argued in its initial "manifesto" that promoting women into senior positions would benefit the editorial content across the paper.

The specifics of their industry did not insulate them from the realities of being women workers, and the Caucus members framed many of their concerns from a labor perspective. ${ }^{20}$ Indeed, the Caucus drew heavily on union support. Caucus leader Betsy Wade was a long-time

1975," Critical Studies in Mass Communication 12, no. 3 (1995): 306-24; Carolyn Bronstein, Battling Pornography: The American Feminist Anti-Pornography Movement, 1976-1986 (Cambridge, MA, 2011); and Bonnie J. Dow, Watching Women's Liberation, 1970 (Urbana, IL, 2014). The feminist "wave" metaphor, which implies a lack of activism and action between waves, may have outgrown its usefulness in terms of assessing feminist practice but is still useful for periodization. Three collections that explore the limitations of the metaphor are Nancy A. Hewitt, ed., No Permanent Waves: Recasting Histories of U.S. Feminism (New Brunswick, NJ, 2010); Kathleen A. Laughlin and Jacqueline L. Castledine, eds., Breaking the Wave: Women, Their Organizations, and Feminism, 1945-1985 (New York, 2011); and Dorothy Sue Cobble, Linda Gordon, and Astrid Henry, Feminism Unfinished: A Short, Surprising History of American Women's Movements (New York, 2014).

${ }^{15}$ Ellen Goodman, "Foreword," in Edge of Change: Women in the 21st Century Press, eds. June O. Nicholson, Pamela J. Creedon, Wanda S. Lloyd, and Pamela J. Johnson (Urbana, IL, 2009), xvii-xxi, here xvii; Povich, The Good Girls Revolt, 69.

${ }^{16}$ Wade interview. These "oaths" were often strategic and surface-level; Kimberly Wilmot Voss has revealed the behind-the-scenes connections between newswomen, and the feminist activists and government officials, who frequently fed them stories. Kimberly Wilmot Voss, Women Politicking Politely: Advancing Feminism in the 1960s and 1970s (Lanham, MD, 2017).

${ }^{17}$ Peggy A. Simpson, “Covering the Women's Movement," Nieman Reports 33, no. 2 (Summer 1979): 19-23, here 19. For objectivity in media, see David T. Z. Mindich, Just the Facts: How Objectivity Came to Define American Journalism (New York, 1998); and Richard L. Kaplan, Politics and the American Press: The Rise of Objectivity, 1865-1920 (Cambridge, MA, 2002).

${ }^{18}$ For the role of news media in shaping representations of women, see Ruth Rosen, The World Split Open: How the Modern Women's Movement Changed America (New York, 2000), ch. 9; and Karen Ross and Carolyn M. Byerly, eds., Women and Media: International Perspectives (Malden, MA, 2004), especially Part I.

${ }^{19}$ This term was artfully coined by Gaye Tuchman in "Introduction: The Symbolic Annihilation of Women by the Mass Media," in Hearth and Home: Images of Women in the Mass Media, eds. Gaye Tuchman, Arlene Kaplan Daniels, and James Benét (New York, 1978), 3-38, here 8.

${ }^{20}$ Alice Kessler-Harris coined "the gendered imagination" to describe a set of gendered beliefs about women in the professional sphere, and particularly about what employers deemed to be the role and purpose of women who worked. Alice Kessler-Harris, In Pursuit of Equity: Women, Men, and the Quest for Economic Citizenship in 20th-Century America (Oxford, UK, 2001), 4-6. See also Alice Kessler-Harris, Out to Work: A History of Wage-Earning Women in the United States (New York, 1982); and Alice Kessler-Harris, Gendering Labor History (Urbana, IL, 2007). 
member of the journalism union. ${ }^{21}$ Formed in 1933, the American Newspaper Guild was a national trade union affiliated with the Congress of Industrial Organizations (CIO). The Guild took a varied approach toward sex discrimination complaints and newswomen's activism in the 1970s. The majority of the day-to-day work focused on local units, which operated in most major cities to represent local papers in negotiations with management, grievances, and implement the Guild contract that determined wages. ${ }^{22}$ Often, as at the Times, the Guild assisted newswomen with salary information and other statistics they could wield against management, although it also initiated and funded sex and race discrimination lawsuits undertaken by members. Throughout the 1970s, the Guild was involved-directly or indirectly-in discrimination complaints and lawsuits at large and small papers across the country. Contrary to common historical understandings of the decline of trade unions following the 1960s, the Guild throughout the 1970s constituted a relatively strong union that had retained its bargaining power. ${ }^{23}$ At the Times, the impact of unions on newswomen was evident. Here, a lawsuit helmed by newswomen with long links to the labor movement and the Guild initially attempted to include women employed at the Times in any capacity in its class action suit, while many other media Title VII lawsuits initiated by newswomen covered only women reporters and editors. ${ }^{24}$

Caucus members made up part of the broader labor tradition that Dorothy Sue Cobble has termed "labor feminists." These women jointly "sought to eliminate sex-based disadvantages" and "articulated a particular variant of feminism that put the needs of working-class women at

\footnotetext{
${ }^{21}$ The media was yet another industry where women were highly underrepresented in the labor movement, and Wade was an exception. As Dorothy Sue Cobble argues in her study of waitress unionists, "the underrepresentation of women in the activities and leadership of the labor movement has been a long-standing problem shared by virtually all unions." Dorothy Sue Cobble, Dishing It Out: Waitresses and Their Unions in the Twentieth Century (Urbana, IL, 1991), 174. The majority of histories of the Guild focus on its early years. See Daniel J. Leab, $A$ Union of Individuals: The Formation of the American Newspaper Guild, 1933-1936 (New York, 1970); Bonnie Brennen, "The Emergence of Class Consciousness in the American Newspaper Guild," in Class and News, ed. Don Heider (Lanham, MD, 2004), 233-47; Dale Benjamin Scott, "Labor's New Deal for Journalism-the Newspaper Guild in the 1930s" (Ph.D. diss., University of Illinois at Urbana-Champaign, 2009); and Philip M. Glende, "Trouble on the Right, Trouble on the Left: The Early History of the American Newspaper Guild," Journalism History 38, no. 3 (Fall 2012): 142-55. For histories of the Guild's later years, see Sam Kuczun, "History of the American Newspaper Guild" (Ph.D. diss., University of Minnesota, 1970); and Catherine McKercher, "From Newspaper Guild to Multimedia Union: A Study in Labour Convergence" (Ph.D. diss., Concordia University, 2000).

${ }^{22}$ Glende, "Trouble on the Right, Trouble on the Left," 142.

${ }^{23}$ Although Turk argues that organized labor's efforts to utilize Title VII did not come "to fruition" until the 1980s, the actions of the Guild who undertook Title VII complaints on behalf of women at newspapers throughout the 1970s extend that periodization back a decade. Turk, Equality on Trial, 6. Nelson Lichtenstein argues that "individual rights and unionism were counterposed in the 1960s and 1970s, to the detriment of both" and that "for much of the union movement, the 1970s and 1980s were a disaster." Nelson Lichtenstein, State of the Union: A Century of American Labor (Princeton, NJ, 2002), 178, 213. Ruth Milkman explicitly links this decline in union power to issues of gender, arguing "the influence of organized labor in the United States has been radically diminished in precisely the same period in which female employment and its contribution to the welfare of working families has expanded so dramatically." Ruth Milkman, "Two Worlds of Unionism: Women and the New Labor Movement," in The Sex of Class: Women Transforming American Labor, ed. Dorothy Sue Cobble (Ithaca, NY, 2007), 63-80, here 63.

${ }^{24}$ Turk argues correctly that despite the initial attempts to force alliances between white-, pink-, and blue-collar workers at the Times, eventually the Caucus abandoned its concerns in order to prioritize women in the professional sphere, and "working class women's remaining concerns ... came to be overshadowed by the struggles and successes of women who entered male-dominated spheres of work." Turk, Equality on Trial, 46. This builds on an argument dating back to at least the 1980s when Ruth Milkman argued that the improvements, particularly in desegregation, of the 1960s and 1970s occurred "primarily because of increased female representation in traditionally male professions ... but the sex composition of the jobs in which most women work has remained stable." Ruth Milkman, Gender and Work: The Dynamics of Job Segregation by Sex during World War II (Urbana, IL, 1987), 153-4.
} 
its core and ... championed the labor movement as the principle vehicle through which the lives of the majority of women could be bettered." ${ }^{25}$ Women employed at mainstream print publications such as the New York Times during the 1970s could hardly be described as working class. ${ }^{26}$ Yet, Cobble also argues that "working-class" can be defined "by low wages or lack of power or just all-around-dismal working conditions," which certainly includes many newswomen working during the $1970 \mathrm{~s}^{27}$ Labor feminism therefore provides a useful category when considering newswomen with no power who worked in poor conditions and did not fit into a feminist tradition, but instead drew on their background in unions and labor organizing. Although labor feminism is traditionally periodized within the 1930s and 1940s, the actions of newswomen demonstrate that working women continued to draw on labor traditions and strategies in meaningful and complex ways throughout the $1970 \mathrm{~s}^{28}$

The Caucus, which drew on both feminist and labor traditions, also followed in the tradition of women's workplace caucuses, which often operated separately from the feminist movement, and relied on the labor and union movements when strategically useful. ${ }^{29}$ Caucus members frequently denied a connection between their activism and either the radical or liberal feminist traditions that continue to dominate "second wave" historiography. ${ }^{30}$ They borrowed activist strategies, including radical feminist consciousness raising and liberal feminist legal action, and championed causes like labor feminist social reforms. Nor were they attached to one side of the ongoing sameness/difference debate over how to position women with regard to men. ${ }^{31}$ When they advocated for equal access to employment opportunities, newswomen made claims of sameness with their male peers. On the other hand, they proved equally willing to wield difference arguments when they insisted that news outlets be required to employ

\footnotetext{
${ }^{25}$ Dorothy Sue Cobble, The Other Women's Movement: Workplace Justice and Social Rights in Modern America (Princeton, NJ, 2004), 3. For labor and working-class feminism, see also Nancy F. Gabin, Feminism in the Labor Movement: Women and the United Auto Workers, 1935-1975 (Ithaca, NY, 1990); and Dennis A. Deslippe, "Rights, not Roses": Unions and the Rise of Working-Class Feminism, 1945-80 (Urbana, IL, 2000).

${ }^{26}$ Indeed, Lichtenstein has noted that Guild founders chose to call themselves a guild rather than a trade union "in deference to the middle-class sensibilities of some of their potential members." Lichtenstein, State of the Union, 40.

${ }^{27}$ Dorothy Sue Cobble, "Introduction," in The Sex of Class: Women Transforming American Labor, ed. Dorothy Sue Cobble (Ithaca, NY, 2007), 1-12, here 3.

${ }^{28}$ For new interpretations of the 1970s, see Stephen Tuck, "Introduction: Reconsidering the 1970s-The 1960s to a Disco Beat?" Journal of Contemporary History 43, no. 4 (Oct. 2008): 617-20; Bruce J. Schulman, The Seventies: The Great Shift in American Culture, Society, and Politics (New York, 2001); Beth Bailey and David Farber, eds., America in the 70s (Lawrence, KS, 2004); Edward D. Berkowitz, Something Happened: A Political and Cultural Overview of the Seventies (New York, 2006); and Jefferson Cowie, Stayin' Alive: The 1970s and the Last Days of the Working Class (New York, 2010). For previous historiography of the 1970s, see Peter N. Carroll, It Seemed Like Nothing Happened: America in the 1970s (New York, 1982). For critiques, see David Frum, How We Got Here: The 70s-the Decade that Brought You Modern Life-For Better or Worse (New York, 2000); and Meg Jacobs and Julian E. Zelizer, "Comment: Swinging Too Far to the Left," Journal of Contemporary History 43, no. 4 (Oct. 2008): 689-93.

${ }^{29}$ For the connection between caucuses and the labor and union movements, see Nancy MacLean, Freedom Is Not Enough: The Opening of the American Workplace (New York, 2006); and Nancy MacLean, "The Hidden History of Affirmative Action: Working Women's Struggles in the 1970s and the Gender of Class," Feminist Studies 25, no. 1 (Spring 1999): 43-78.

${ }^{30}$ This article avoids these distinctions entirely, because as Sara M. Evans has argued, by 1970 the boundaries between factions were "seriously blurred," and "the thousands of women who were drawn to the movement frequently did not know or care which direction they went." Sara M. Evans, "Beyond Declension: Feminist Radicalism in the 1970s and 1980s," in The World the 60s Made: Politics and Culture in Recent America, eds. Van Gosse and Richard Moser (Philadelphia, 2003), 52-66, here 52, 55, 64.

${ }^{31}$ Estelle B. Freedman has argued that the women's liberation movement was the point when "two competing strains of equality and difference began to converge." Estelle B. Freedman, No Turning Back: The History of Feminism and the Future of Women (New York, 2002), 5. For the contradictions in the sameness/difference debate, see also Gisela Bock and Susan James, eds., Beyond Equality and Difference: Citizenship, Feminist Politics and Female Subjectivity (London, 1992).
} 
women in order to sufficiently and equitably cover women as news subjects. Newswomen were comfortable tactically shifting their arguments depending on their audience and the issue.

\section{Forming the Women's Caucus}

After a long struggle to get in the door, by the 1970s a critical mass of women existed in mainstream newsrooms, albeit mostly white, middle-class, educated women. ${ }^{32}$ Historically, newswomen had made themselves indispensable to newspapers, particularly through "stunt reporting" at the turn of the century. ${ }^{33}$ By 1930 women comprised approximately 22 percent of the journalistic workforce, although they still struggled to gain entry into many facets of the profession. ${ }^{34}$ They were assisted by wartime vacancies, but as in many industries, often found themselves let go in the post-World War II period when their male colleagues returned. In the 1960s, the numbers of newswomen rose to 37 percent, although these statistics also included women employed at so-called "women's magazines." 35 By the 1970s, women still comprised a minority of journalists, but were no longer likely to be the only woman on staff, in part thanks to the development of the women's pages in the post-war period. ${ }^{36}$ According to the U.S. Census, the fraction of women "editors and reporters" rose from 37 percent in 1960 to 40 percent in 1970, although these numbers were again boosted by the numbers of women working at women's magazines. ${ }^{37}$ In 1970, women editors and reporters made a median annual salary of $\$ 5,530$, almost half what men made at $\$ 10,618$, despite comparable weeks worked and school years completed. ${ }^{38}$

The mostly white, middle-class, educated women who had worked their way into the New York Times newsroom became the Caucus's first targets in the months following their

\footnotetext{
${ }^{32}$ The modern historiography of women in media is widely regarded to have commenced with Marion Marzolf, Up from the Footnote: A History of Women Journalists (New York, 1977). Marzolf's work and theory of "professionalism" have been expanded and complicated by subsequent media scholars, most notably Catherine L. Covert, "Journalism History and Women's Experience: A Problem in Conceptual Change," Journalism History 8, no. 1 (Spring 1981): 2-6; Susan Henry, "Changing Media History through Women's History," in Women in Mass Communication: Challenging Gender Values, ed. Pamela J. Creedon (Newbury Park, CA, 1989), 34-57; and Maurine H. Beasley, "Recent Directions for the Study of Women's History in American Journalism," Journalism Studies 2, no. 2 (2001): 207-20.

${ }^{33}$ See Patricia Bradley, Women and the Press: The Struggle for Equality (Evanston, IL, 2005), ch. 6; Jean Marie Lutes, Front Page Girls: Women Journalists in American Culture and Fiction (Ithaca, NY, 2006); and Alice Fahs, Out on Assignment: Newspaper Women and the Making of Modern Public Space (Chapel Hill, NC, 2011).

${ }^{34}$ Elizabeth V. Burt, "Introduction," in Women's Press Organizations: 1881-1999, ed. Elizabeth V. Burt (Westport, CT, 2000), xvii-xxxi, here xvii-xxv.

${ }^{35}$ Bradley, Women and the Press, 230.

${ }^{36}$ For women's pages, see Mei-ling Yang, "Women's Pages or People's Pages: The Production of News for Women in the Washington Post in the 1950s," Journalism and Mass Communication Quarterly 73, no. 2 (June 1996): 364-78; Rodger Streitmatter, “Transforming the Women's Pages: Strategies That Worked," Journalism History 24, no. 2 (Summer 1998): 72-81; Dustin Harp, Desperately Seeking Women Readers: U.S. Newspapers and the Construction of a Female Readership (Lanham, MD, 2007); and Kimberly Wilmot Voss, Re-Evaluating Women's Page Journalism in the Post-World War II Era (Cham, Switzerland, 2018).

${ }^{37}$ U.S. Census Bureau, 1960 Census: Population, Subject Reports, Occupational Characteristics: Data on Age, Race, Education, Work Experience, Income, Etc., for the Workers in Each Occupation, Final Report PC(2)-7A, "Detailed Occupation of the Experienced Civilian Labor Force, by Sex, for the United States, Urban and Rural: 1960," table 1, https://www2.census.gov/library/publications/decennial/1960/population-volume-2/41927947v2p7a-7bch2. pdf (accessed July 26, 2020), 1; U.S. Census Bureau, 1970 Census-Population, Subject Reports: Occupational Characteristics, Final Report PC(2)-7A, "Summary of Social and Economic Characteristics of the Experienced Civilian Labor Force by Detailed Occupation and Sex: 1970," table 1, https://www2.census.gov/library/publications/ decennial/1970/pc-2-7a/42045403v2p7a7bch01.pdf (accessed July 26, 2020), 1.

${ }^{38}$ U.S. Census Bureau, 1970 Census-Population, Subject Reports: Occupational Characteristics, Final Report PC (2)-7A, "Summary of Social and Economic Characteristics of the Experienced Civilian Labor Force by Detailed Occupation and Sex: 1970," table 1, https://www2.census.gov/library/publications/decennial/1970/pc-2-7a/ 42045403v2p7a7bch01.pdf (accessed July 26, 2020), 2.
} 
initial lunch in February 1972. Instigator Grace Glueck retired to her apartment with several of the other attendees and began the four-month-long process of drafting and redrafting their manifesto. Slowly the small group consulted with more and more women in the Times newsroom, and the women who assembled became the founding members of the Caucus. Glueck's frustrations with the Times dated earlier than organizing the Caucus, and even before a highly publicized feminist sit-in at Ladies' Home Journal or the Newsweek complaint, both in 1970. In 1969, she had written in outrage to Times publisher Arthur Ochs Sulzberger after the latest round of key management changes once again failed to include any women. Unbeknownst to Glueck, the letter rattled the publisher, who had spoken to management about the possibility of women on the paper organizing. ${ }^{39}$ Thus, media women began organizing before the publicity of the 1970 Newsweek complaint, although it did inspire many women-including Glueck-to intensify their activism.

Joining Glueck in the initial stages of organizing was an amorphous group of Times newswomen who experienced a moment of consciousness-raising when Glueck and the other Caucus leaders approached them about their grievances and convinced them to sign the letter to management. ${ }^{40}$ This was the kind of moment Jane O'Reilly had in mind when she coined "click!" in Ms. magazine to describe "the shock of recognition" and "instant sisterhood" that occurred when women recognized their experiences in each other as systemic rather than individual. ${ }^{41}$ Women held these discussions quietly and informally at their desks and throughout the Times building.

Betsy Wade, whom Glueck had recruited to the organizing lunch, became her primary collaborator and eventually the Caucus's de facto leader. Wade was the newly appointed head of the foreign copy desk, and her promotion made her the most senior woman in the newsroom outside of the paper's management, as well as the only woman in a senior role traditionally held by a man. ${ }^{42}$ When hired at the Times in 1956 as the first female copyreader, male colleagues welcomed her by decorating her paste pot with petticoat ruffles. ${ }^{43}$ Although she eventually became less of an "amusing mascot," Wade's hiring certainly did not mark a major shift in recruiting women for senior positions. ${ }^{44}$ In 1971, after a party at her boss's house, Wade's husband noted the attendees were "almost 100 percent Times men and their wives, showing again how isolated B. is in her department even after all these years." 45 Despite her senior position, Wade claimed she had been "refused access" to jobs that provided a "route to promotion."

\footnotetext{
${ }^{39}$ Robertson, The Girls in the Balcony, 133-5.

${ }^{40}$ The idea of feminist consciousness-raising was first outlined by Kathie Sarachild in 1968 at the First National Women's Liberation Conference, who described it in a later publication as "studying the whole gamut of women's lives, starting with the full reality of one's own." Kathie Sarachild, "Consciousness-Raising: A Radical Weapon," in Feminist Revolution: Redstockings of the Women's Liberation Movement, ed. Kathie Sarachild (New York, 1978), 144-50. See also Voichita Nachescu, "Radical Feminism and the Nation: History and Space in the Political Imagination of Second-Wave Feminism," Journal for the Study of Radicalism 3, no. 1 (Spring 2009): 29-59. Although Sarachild coined the term, Alice Echols noted that the strategy "did not originate" with feminists and was instead inspired by the civil rights movement and other groups. See Alice Echols, Daring to Be Bad: Radical Feminism in America, 1967-1975 (Minneapolis, MN, 1989), 83-4; and Rebecca Tuuri, "This was the most meaningful thing that I've ever done': The Personal Civil Rights Approach of Wednesdays in Mississippi," Journal of Women's History 28, no. 4 (Winter 2016): 89-112.

${ }^{41}$ Jane O'Reilly, "The Housewife's Moment of Truth," Ms., Spring 1972, 54.

${ }^{42}$ Robertson, The Girls in the Balcony, 141; Povich, The Good Girls Revolt, 157.

${ }^{43}$ Robertson, The Girls in the Balcony, 84-5.

${ }^{44}$ Betsy Wade, "Footnote," in Wade interview appendix.

${ }^{45}$ Quoted in Robertson, The Girls in the Balcony, 141.

${ }^{46}$ Elizabeth Boylan (Betsy Wade), "New York City Commission on Human Rights" form, undated, folder 24, box 2, New York Times Women's Caucus Papers, Schlesinger Library, Radcliffe Institute, Harvard University, Cambridge, MA [hereafter NYTWC].
} 
Wade was a valuable ally for a reason other than her seniority; she had been long-involved in the Guild, the union representing the majority of employees at the Times. The New York unit oversaw the New York Times, New York Daily News, and New York Post, and Guild membership was composed of employees from all departments at these papers, rather than just from the newsroom. Wade, also a founding member of the New York Coalition of Labor Union Women, brought both labor organizing tactics and her Guild contacts to the Caucus. ${ }^{47}$ The Guild had funds and clout at its disposal and was a valuable ally to have. It was also conveniently located on West 44th Street, around the corner from the Times on West 43rd, making it easy for Wade or other Caucus women to drop in as necessary. ${ }^{48}$

Together with other Caucus members, Wade and Glueck quietly set about finding what "dust was under the rug" at the Times to include in their letter to management. ${ }^{49}$ In addition to noting several departments completely devoid of women, they discovered that the Times was a federal contractor, and as such was subject to Executive Order 11246, which was signed in 1965 by President Lyndon Johnson and "resurrected" by President Richard Nixon in 1969. 50 The order required government contractors to "take affirmative action" to ensure nondiscriminatory practices. ${ }^{51}$ Based on this order, and after consulting on the specific regulatory language with Eileen Shanahan, another Caucus member who was the paper's star economics reporter from the Washington, DC bureau and who had begun to cover the Equal Rights Amendment for the Times, they added a demand for an affirmative action plan to their letter. ${ }^{52}$ Caucus members envisioned this affirmative action plan as the solution to the problems for women working across the paper's news departments, and it would structure Caucus negotiations for the next few years.

Although some Times newswomen were driven to activism by these findings, not all women saw the strategic value in joining in. The Caucus found it difficult to convince their colleagues to sign the letter and recalled "fear" and "almost an inbred, white-gloved reluctance" because "ladies didn't do that sort of thing." 53 Two of the paper's most senior women, Charlotte Curtis, the family/style editor, and Ada Louise Huxtable, the paper's venerated architecture critic, refused to sign the letter entirely. Curtis, who Caucus member Nan Robertson claimed "promoted herself as a liberal and a feminist," would later tell the media that "the women's charges against the paper are generally true," but she never aligned herself with the Caucus because, according to Robertson's memoir, she “didn't want to be used by the women's group or management." 54

\footnotetext{
${ }^{47}$ MacLean, "The Hidden History of Affirmative Action," 57.

${ }^{48}$ Anthony Ramirez, "Guild Building Tentatively Sold for Hotel Space," New York Times, Dec. 22, 1996, https://www. nytimes.com/1996/12/22/nyregion/guild-building-tentatively-sold-for-hotel-space.html (accessed May 24, 2018).

${ }^{49}$ Wade interview.

${ }^{50}$ Thomas J. Sugrue, "Affirmative Action from Below: Civil Rights, the Building Trades, and the Politics of Racial Equality in the Urban North, 1945-1969," The Journal of American History 91, no. 1 (June 2004): 145-73, here 171.

${ }^{51}$ Executive Order No. 11246, Sep. 24, 1965, "Equal Employment Opportunity," 30 F.R. 12319, https://www. archives.gov/federal-register/codification/executive-order/11246.html (accessed July 26, 2020).

${ }^{52}$ Grace Glueck, Memo, May 8, 1972, folder 19, box 1, NYTWC.

${ }^{53}$ Robertson, The Girls in the Balcony, 146.

${ }^{54}$ Robertson, The Girls in the Balcony, 149; Judith Coburn, "Women Take the New York Times to Court," New Times, Oct. 2, 1978, 22; Lindsy Van Gelder, "Women vs. the New York Times," Ms., Sep. 1978, 68. In her biography of Curtis, Marilyn S. Greenwald argues that Curtis was more sympathetic to the women's case than she had subsequently been portrayed and gives weight to arguments that Curtis could not have participated in the lawsuit because she was an editor and therefore "part of the management group." However, Wade's position as an editor did not curtail her involvement, and this also does not explain why Curtis did not sign on to the 1972 letter, years before the Caucus instigated its lawsuit. It is more likely that Curtis, like the Caucus members, made a strategic assessment of the value of her involvement and simply came up with a different answer. Marilyn S. Greenwald, A Woman of the Times: Journalism, Feminism, and the Career of Charlotte Curtis (Athens, OH, 1999), 125-9.
} 
Opposition to the Caucus's activities extended beyond this internal pushback. This became especially evident when the Caucus's plans leaked early, despite attempts at secrecy. While in the process of recruiting signatories, Wade, Glueck, and nine other women were invited by the paper's domineering managing editor, A. M. Rosenthal, to a meeting about "the whole question of women and the newspaper business in general and women and The New York Times in particular." 55 A Caucus member recalled that during the meeting, Rosenthal acted "wounded" and asked why the women had not first approached him with their concerns, just as male reporters did. Wade, who believed the meeting was intended to "head [them] off at the pass" said it only "stiffen[ed] the resolve of the women because they began to see that this was not something where explaining what the problem was was going to bring an instant solution." 56 Another Caucus member observed, "We were there to raise Abe's consciousness, which he didn't want raised." 57 The meeting ended in a stalemate.

After four months of work from their initial lunch, the Caucus delivered their letter to the publisher and the paper's managing editors, including Rosenthal, on Memorial Day, May 29, 1972. They also sent copies to the publisher's sisters and mother, who were members of the board, in the hope that they might offer a more sympathetic ear. The letter laid out statistics supplied by the Times about women across the newsroom. There were no women among the twenty-one names on the eminent masthead, no women among the ten vice presidents, and no senior women within any of the departments from which vice presidents were most frequently chosen. The Times could claim no women editorial editors, no women columnists, no women national desk correspondents, no women photographers, and no women music, drama, television, or book reviewers. Of thirty-five foreign correspondents there were only three women, and of thirty-one critics and reporters in cultural news there were four women. Business and financial news had twenty-one men and three women, sports had twenty-three men and one woman, and of seventy-five copyreaders, only four were women. The Washington, DC bureau employed only three women, a number that had not increased in the past decade, despite the staff of the bureau doubling in that time to thirty-eight reporters. In total, the daily paper operated with only forty women reporters compared with 385 male reporters, and the Sunday department operated with twenty-one women compared with fifty-eight men. Of the three most senior women on the paper, two-one of whom was Curtis-held jobs the Caucus described as "traditionally held by women" in the informally gender segregated family/style department; Wade was the exception, and none had significant impact on the paper's "overall policies."

In addition, citing a 1968 breakdown of women's and men's salaries, the Caucus determined that, on average, the Times paid women less at every age. They attributed this to "the lowerpaying jobs to which women are confined," but noted examples of women being paid less than their male counterparts in the same jobs. Finally, the Caucus criticized the culture at the paper that "encouraged" men to "think in larger goals" by providing better assignments and promising promotions, while "few executives seriously entertain" the same opportunities for women. This later section lacked the firm statistical base of the opening, but that did not stop the Caucus from citing the paper's responsibilities under the Civil Rights Act of 1964 to "adopt an affirmative action program with regard to women, establishing goals and timetables." The Caucus laid out five key goals: reviewing and rectifying salary inequities; new procedures to ensure "full use of the talents" of women in the news, Sunday, and editorial departments; new hiring practices to "increase the number and proportion of women reporters"; promoting women to more senior positions with greater responsibility; and a program

\footnotetext{
${ }^{55}$ A. M. Rosenthal to Charlotte Curtis et al., May 18, 1972, folder 7, box 95, A. M. Rosenthal Papers, New York Times Company Records, New York Public Library, New York, NY [hereafter AMRP].

${ }^{56}$ Robertson, The Girls in the Balcony, 148; Wade interview.

${ }^{57}$ Robertson, The Girls in the Balcony, 149.
} 
to explicitly hire women for positions from which they were currently excluded. The letter ended with a statement that the Caucus looked forward to receiving a "specific timetable for the achievement of such an affirmative action program." 58

The completion of the letter to Times management marked the end of the first sustained period of consciousness-raising in the newsroom. The meeting with Rosenthal had divided women, and Curtis's and Huxtable's opposition may have dissuaded others from participating. In the end, forty-nine newswomen took the risk of retaliation and signed the letter, choosing to put their name to their shared grievances. For the first few months, the slowly forming Caucus, led by Glueck and Wade, had been focused entirely on recruiting as many women as possible and making their letter as strong as they could. Moving forward, the Caucus would experiment with different activist strategies and techniques beyond letter writing and consciousness-raising in order to combat intense resistance from Times management. But first, they had to meet them face to face.

\section{Testing Grassroots Strategies}

It took two months for Times management to arrange a meeting with Caucus representatives after receiving the letter. ${ }^{59}$ Caucus members did not waste this time. They turned to their union for support; using Wade's contacts in the Guild, they obtained further salary information about men and women at the Times, with the names redacted. From the Guild's numbers, the women discovered an average difference of $\$ 59$ a week between men's and women's salaries. ${ }^{60}$ They found that of this group, 23 percent of women worked at a minimum union salary, compared with only 6.8 percent of men. The Caucus also made use of the Times pension plan, of which Wade was a Guild trustee and therefore had access. The pension information demonstrated a similar pay discrepancy. Because every employee had been hired at a different initial rate and received different increases-as was standard in the industry-each salary at the Times was unique. Therefore, even with the names redacted, each Caucus member could easily find her own salary on the list and see exactly how much the Times valued her. This financial information finally convinced those Caucus members who were still unsure, with one recalling, "we really hit the ceiling." Just like their lunch at Act One, comparing salaries forced the women to reckon with the systemic problems across the Times. They no longer believed they as individuals were being held back or did not have the skills to advance. In addition, Wade said the financial information reinforced a further dilemma for a group of women who had dedicated much of their working lives to the Times. "It required us to look at what we wanted for the paper," she said. "We all wanted the paper to be better than it was." 61

With a meeting with management scheduled for July 19, 1972, the Caucus members made a monumental step: they contacted a lawyer. The evening before their meeting, Caucus members squeezed into Grace Glueck's tiny apartment on East 63rd Street to listen to Professor George Cooper and Assistant Dean Harriet Rabb of Columbia Law School's Employment Rights Project brief them on their rights and the laws of sex discrimination. ${ }^{62}$ Such was the level of interest that Wade remembers "sitting with [her] head in a bookshelf" just to fit into the room. ${ }^{63}$ The Employment Rights Project was established in 1971, and Rabb and Cooper had become the experts in the new field of sex discrimination law. Their program was a clinical course, which allowed Columbia students to work on real cases under Cooper's and Rabb's supervision. By 1972, the clinic had taken on cases from women at the New York

\footnotetext{
${ }^{58}$ Women's Caucus to Arthur Ochs Sulzberger et al., undated, folder 32a, box 3, NYTWC.

${ }^{59}$ Arthur Ochs Sulzberger to Women's Caucus, June 1, 1972, folder 7, box 95, AMRP.

${ }^{60}$ Robertson, The Girls in the Balcony, 13.

${ }^{61}$ Ibid., 144.

${ }^{62}$ Ibid., 154.

${ }^{63}$ Wade interview.
} 
Telephone Company, New York University School of Law, and Columbia Law School. ${ }^{64}$ More crucially to the Caucus, the clinic also handled the latest round of negotiations at Newsweek. Given the legal intricacies of this still-developing area, lawyers were crucial in navigating Title VII of the Civil Rights Act of 1964. Rabb-who eventually took primary responsibility for the clinic and for the Times lawsuit-had got in early on the ground, and she quickly established herself as the "foremost Title VII lawyer in the business." 65

Women newsroom workers, like the Caucus, could take action with the assistance of Rabb and other lawyers because of the legislative and legal changes introduced in the 1960s and 1970s. ${ }^{66}$ The most often deployed of these was indeed Title VII, locked onto by feminists from the moment Congressman Howard Smith proposed adding "sex" to the bill on the House floor at the last minute. Historians have long debated whether Smith, an opponent of civil rights, intended to scuttle the bill. ${ }^{67}$ For the mainstream media, the "sex" clause elicited mirth; the New York Times wondered "how employers would cope with women applying for jobs as truck drivers or men applying for jobs as salesmen in lingerie departments," and later joked that "federal officials ... may find it would have been better if Congress had just abolished sex itself." 68 The addition of "sex" complicated the role of the newly formed EEOC, which received 37 percent of complaints in its first year on the basis of sex discrimination. ${ }^{69}$ The Equal Employment Opportunity Act of 1972 bolstered the commission's powers by giving the EEOC the authority to initiate a lawsuit and act as a plaintiff, rather than acting as a mediator or encouraging workers to sue. The "rights revolution" built upon these immense legislative and legal changes ushered in major transformations in race, gender, and work. $^{70}$

It is unclear from the archive exactly how the Caucus found Rabb and Cooper. As Wade recalled, lawyers handling sex discrimination litigation were certainly "in the news." ${ }^{\text {71 }}$ There are some suggestions that Caucus member Grace Lichtenstein put forward Rabb's name. In all likelihood the Times women-possibly Lichtenstein herself, who covered the feminist movement for the paper-knew of Rabb through her work on the Newsweek case beginning in October 1971. ${ }^{72}$ Although the Caucus records reveal that Rabb was involved from July 1972,

\footnotetext{
${ }^{64}$ Harriet S. Rabb, "Litigating Sex Discrimination Cases in the 1970s," Columbia Journal of Gender and Law 25, no. 1 (Summer 2013): 50; "History in the Making: Four Pioneers Trace the Origins of Clinical Education at Columbia Law School," Columbia Law School, https://web.law.columbia.edu/clinics-celebration-2015/recap/panels-discussions/history-in-making (accessed July 26, 2020).

${ }^{65}$ Lindsy Van Gelder, "Harriet Rabb, Scourge of Corporate Male Chauvinism," New York Magazine, June 26, $1978,38$.

${ }^{66}$ Sophia Lee argues the 1960s saw an extension of the "workplace Constitution," an idea that "workers had constitutional rights on the job and in the union," which dated from the 1920s, and that this Constitution supplemented Title VII in efforts, particularly by African Americans, to protect black workers. Sophia Z. Lee, The Workplace Constitution from the New Deal to the New Right (New York, 2014), 2.

${ }^{67}$ See Cynthia Harrison, On Account of Sex: The Politics of Women's Issues, 1945-1968 (Berkeley, CA, 1988), 176-82; Jo Freeman, "How 'Sex' Got into Title VII: Persistent Opportunism as a Maker of Public Policy," Law and Inequality 9, no. 2 (1991): 163-84; Kessler-Harris, In Pursuit of Equity, 241-6; and Serena Mayeri, Reasoning from Race: Feminism, Law, and the Civil Rights Revolution (Cambridge, MA, 2011), $20-3$.

68“The Nation,” New York Times, July 4, 1965, E1; “De-Sexing the Job Market,” New York Times, Aug. 21, $1965,20$.

${ }^{69}$ Kessler-Harris, In Pursuit of Equity, 246-7.

${ }^{70}$ MacLean, Freedom Is Not Enough, 2. See, for instance, the well-documented case of sex discrimination at AT\&T in Lois Kathryn Herr, Women, Power, and AT\&T: Winning Rights in the Workplace (Boston, 2003); and Marjorie A. Stockford, The Bellwomen: The Story of the Landmark AT\&T Sex Discrimination Case (New Brunswick, NJ, 2004). For the landmark Supreme Court case on employment discrimination, see Robert Samuel Smith, Race, Labor, and Civil Rights: Griggs versus Duke Power and the Struggle for Equal Employment Opportunity (Baton Rouge, LA, 2008); and Robert Belton, The Crusade for Equality in the Workplace: The Griggs v. Duke Power Story (Lawrence, KS, 2014).

${ }^{71}$ Wade interview.

${ }^{72}$ Wade interview; Povich, The Good Girls Revolt, 129.
} 
Caucus members do not recall contacting her until 1973, after several rounds of exhausting and failed negotiations with Times management. ${ }^{73}$ These recollections contribute to the prevailing narrative within the existing historiography that the Caucus was forced to seek legal action only after a lack of response by the Times. In contrast, the fact that they contacted Rabb so early and sought to arm themselves with the necessary legal definitions and terms underscored both the Caucus members' desire to have all of the facts before proceeding-a quality perhaps unremarkable in a group of journalists-but also their willingness to wield legal strategies, even before they knew what the publisher's response would be. Indeed, the threat of litigation had been present as early as their initial letter to management, when the Caucus members noted in their opening paragraph that women had been "compelled to take remedial action to assert their rights" in cases when pressure alone had not seen improvement. ${ }^{74}$ This does not mean the Caucus had pre-emptively decided to take legal action, but is rather further evidence of their own attentiveness, as demonstrated through their desire to cover all of their bases and to be ready for any eventuality.

That night in July, Rabb and Cooper spent an evening explaining the intricacies of sex discrimination law to the assembled journalists, including the complicated procedures for filing complaints with different government bodies, how to establish patterns of discrimination, and how to compute equitable salaries. ${ }^{75}$ Rabb recommended the Caucus aim for a prima facie case that demonstrated "women are limited, segregated or classified to levels of employment ... not given the same opportunities to be hired or advanced ... or that conditions of employment are such that women are concentrated in certain kinds of jobs or substantive areas." ${ }^{76}$ Until the late 1960s, newspapers segregated job advertisements by sex, and the matter was not settled until the Supreme Court ruled the practice discriminatory in $1973 .^{77}$ Nevertheless, Rabb believed establishing "patterns which cannot be justified" was crucial to making the Caucus's case. ${ }^{78}$ By the next morning, Rabb's lessons had influenced the rhetoric adopted by the Caucus, and particularly Wade, its elected spokesperson. In the huge and formidable board room on the fourteenth floor of the Times building, Wade sat to Sulzberger's left and across from the Times's heavy hitters-all men. Notably missing were Sulzberger's sisters and mother. The arrangements of the mahogany-paneled room made clear that the paper's controlling family had decided to put up a united front behind the editor himself. ${ }^{79}$

The initial meeting began a long process of negotiation between Caucus representatives and Times management, which lasted until 1974. Wade described the various resulting subcommittees as "absolutely futile and pointless," suggesting that "nobody seemed to have told people in management that they were to find a solution. So without instructions from on high, they simply floundered around." ${ }^{80}$ While little improvement occurred thanks to the subcommittees, the Caucus members busily set up the internal infrastructure that would support their endeavors over the next few years. They had already democratically sourced a team of delegates to meet with management, by requesting that Caucus members nominate women who they would be happy to have represent them. ${ }^{81}$ This list included Betsy Wade, Grace Glueck, and

\footnotetext{
${ }^{73}$ Povich, The Good Girls Revolt, 154-9; Robertson, The Girls in the Balcony, 158.

${ }^{74}$ Women's Caucus to Arthur Ochs Sulzberger et al., undated, folder 32a, box 3, NYTWC.

${ }^{75}$ Caucus meeting notes, July 18, 1972, folder 32a, box 3, NYTWC.

${ }^{76}$ Ibid.

${ }^{77}$ Pittsburgh Press Co. v. Human Relations Commission, 413 U.S. 376 (1973); "Sex as Job Basis Is Barred in Ads," New York Times, Mar. 28, 1971, U39; “Law on Sex-Labeled Job Ads Is Upheld,” New York Times, June 22, $1973,11$. See also Nicholas Pedriana and Amanda Abraham, "Now You See Them, Now You Don't: The Legal Field and Newspaper Desegregation of Sex-Segregated Help Wanted Ads 1965-75," Law \& Social Inquiry 31, no. 4 (Autumn 2006): 905-38.

${ }^{78}$ Caucus meeting notes, July 18, 1972, folder 32a, box 3, NYTWC.

${ }^{79}$ Robertson, The Girls in the Balcony, 3-10.

${ }^{80}$ Wade interview.

${ }^{81}$ Memo to Times Women, July 26, 1972, folder 18, box 1, NYTWC.
} 
Joan Cook, a reporter at the Times's New Jersey bureau and a long-time friend of Wade's, who was a fellow unionist and the third member of the "guiding troika of the caucus" according to one Caucus member. ${ }^{82}$ Together they put up notices on bulletin boards, mirrors, and on the backs of doors in the women's restroom stalls. They did mailings throughout the Times building and negotiated with the Times's internal postal department to distribute them. ${ }^{83}$ They collected newspaper articles about sexism and racism in the media, and feminist action around the country. ${ }^{84}$ They also established a newsletter for women at the Times. The first issue, dated September 7, 1972, brought Caucus members up to date on the fruitless discussions with management and alerted them to the support offered by their union. ${ }^{85}$ By October, the Caucus referred to Rabb as their "consulting lawyer" in the newsletter, although it is likely that she unofficially held this role from their first meeting in July. ${ }^{86}$ The Caucus was able to engage Rabb free-of-charge, because the Employment Rights Project was partially funded by the EEOC, staffed by students, and Rabb's salary was paid by Columbia Law School.

Within the Caucus, the subject of a lawsuit never quite disappeared during these early meetings, and was again the key topic of discussion in November 1972. Wade reported at a meeting that the Guild had again asked how it could help the case, "with a possible view to a court action" and "that the Guild stands ready to help." The second topic of the November meeting was the related and equally practical concern of opening up Caucus membership to nonreporters. This subject proved more divisive, and according to Wade the meeting was "rough." ${ }^{87}$ Before the meeting, Wade had written to the Times Vice President for Industrial Relations seemingly heralding a lawsuit, by reminding him of "the remedies available ... if no progress is demonstrated." ${ }^{\prime 8}$ Now it seemed time to determine exactly who such a lawsuit would cover. Wade and Cook-the union women-were "absolutely adamant" that any action must be brought on behalf of all women employed by the paper rather than only journalists, and argued "if [they] couldn't take everybody along, what the hell were [they] doing it for?" 89 During the discussion, Wade explicitly referenced "court action," suggesting it would only be possible if the Caucus broadened its scope. Rabb also wanted a potential suit brought on behalf of all women at the Times, including those who were unable to join the various other unions operating at the paper, including the printers' and paperhandlers' unions. As Wade described it, Rabb trained her eyes "not simply on the terrestrial globe, she was looking at outer space." 90

Other members opposed expanding the Caucus, arguing that "if the response by other women is a minority response, this would hurt rather than help." Some members thought a larger group would be "unwieldy" and cited "problems of communication." 91 Perhaps they believed that sourcing women from the accounting offices on the eighth floor or the classified department on the sixth floor would be too complicated. This argument was somewhat disingenuous, considering the Caucus already included women from the third-floor city room containing the majority of reporters, the eighth-floor Sunday department, and family/ style on the ninth floor-as well as from separate bureaus in New Jersey and Washington, DC. ${ }^{92}$ Indeed, there existed a longer history to this conflict between reporters and other newspaper staff. Before joining the CIO in 1937, the Guild had initially affiliated with the American

\footnotetext{
${ }^{82}$ Ursula to Betsy Wade, undated, folder 25, box 2, NYTWC.

${ }^{83}$ Wade interview.

${ }^{84}$ For a range of these clippings, see folder 16, box 1, NYTWC.

${ }^{85}$ Caucus newsletter, Sep. 7, 1972, folder 25, box 2, NYTWC.

${ }^{86}$ Grace Glueck to Negotiating Committee, Oct. 9, 1972, folder 18, box 2, NYTWC.

${ }^{87}$ Wade interview.

${ }^{88}$ Betsy Wade to John Mortimer, Nov. 9, 1972, folder 17, box 1, NYTWC.

${ }^{89}$ Wade interview.

${ }^{90}$ Ibid.

${ }^{91}$ Caucus meeting notes, Nov. 9, 1972, folder 18, box 1, NYTWC.

${ }^{92}$ Robertson, The Girls in the Balcony, 3, 40, 78, 176.
} 
Federation of Labor, a move indicative of the disagreement Guild members felt over whether the newly formed union represented workers united by their craft or their industry. A year later, members voted to join the CIO instead, in order to open Guild membership to nonreporters and non-editorial workers. ${ }^{93}$ Although the tension between craft and industry was settled by the 1970s within the Guild, it played out again in conversations between newswomen struggling with whether their activism should encompass newsroom workers only or all women employed at their news outlet. This decision often came down to a question of legal strategy, as Katherine Turk has demonstrated. ${ }^{94}$ Expanding the class definition required the mostly white and mostly middle-class newswomen to wrestle with class and race identities not represented in the newsroom, and which they did not always deem strategically pertinent. Newswomen at different outlets made different strategic decisions on whether to proceed on a craft or an industry basis, and many chose to focus on newswomen to the exclusion of other professions. If they decided to include all women, as long-time unionist Betsy Wade advocated for at the Times, they then faced a decision about whether or not to prioritize the specific needs of women outside the newsroom.

Wade later suggested the reluctance of certain Caucus members to expand was based in "elitism," "hostility," and "a sort of contempt" toward non-creative types outside of the news department. She recalled somewhat naively that at the time she did not feel that her opinion was weighted more than others or that she would "polarize the issue," yet even in late 1972 Wade had emerged as the clear leader of the Caucus, and it is unlikely her opinions were quite as neutral as she suggested. ${ }^{95}$ Indeed, the Caucus members must have found her position persuasive, because that night in November they reached a consensus to broaden their group by informally approaching women throughout the building-likely in the communal cafeteria on the eleventh floor or in the women's restrooms. ${ }^{96}$ By January 1973, this informal approach had morphed into an active outreach attempt, and the Caucus's Negotiating Committee sent a memo soliciting interest to women across the paper. ${ }^{97}$ At the February meeting, "About 60 women from all job levels attended, representing a large number of departments, including [Times-owned radio station] WQXR, Classified, Communications and some departments based outside The Times Building."

Having experimented with newsletters, further outreach, drawing on their links to the labor movement, and increasing their legal knowledge, the Caucus now looked very different than it had when sending the original complaint letter to management. Although its varied strategies had much in common with other 1970s feminists, noticeably absent from the Caucus's activism was a direct connection to these activists themselves. This was despite the fact that the Times, a pinnacle of journalism, was often the target of other feminist action. Given the Caucus's willingness to look broadly for support and test different techniques, this calculation to distance itself from the feminist movement must have been strategic and influenced its actions as its struggle against Times management continued.

\section{Navigating Feminist Activists}

The Times was the target of feminist activists beyond those who comprised the Caucus. However, those women journalists who covered the feminist movement often distanced themselves from it, and by late 1972 an explicit divide between these different activists had emerged. When the male Sunday editor was replaced with another man in September 1972, a group of

\footnotetext{
${ }^{93}$ Glende, "Trouble on the Right, Trouble on the Left," 142.

${ }^{94}$ Turk, Equality on Trial, ch. 2.

${ }^{95}$ Wade interview.

${ }^{96}$ Caucus meeting notes, Nov. 9, 1972, folder 18, box 1, NYTWC.

${ }^{97}$ Negotiating Committee to Times Women, Jan. 1973, folder 32c, box 3, NYTWC.

${ }^{98}$ Negotiating Committee to Times Women, Mar. 14, 1973, folder 32c, box 3, NYTWC.
} 
feminist journalists and freelancers, including Susan Brownmiller and Nora Ephron, contacted Times women who wrote for the Sunday section. Brownmiller had achieved fame through her successful 1970 feminist sit-in at Ladies' Home Journal. Now, she and others had drafted a letter to the male editor about the "participation of women on every level of the Sunday department" and requested "the Sunday section seek out and hire women for important jobs." "99 Apparently unaware of the actions Sunday Times women were already taking to address these grievances as part of the Caucus, they did not seek coordination with them.

Feminists working outside the Times and the Caucus often desired similar outcomes. As early as June 1972, after the Caucus had delivered their letter to the publisher and were in the process of scheduling their first meeting, Rosenthal met with representatives from the New York chapter of NOW, later characterizing them as "helpful, pleasant, and extremely wellinformed." In a memo addressed to all the editors, including Wade, but which quickly passed to other Caucus members, Rosenthal reported that the group had provided "a study of The New York Times in relation to women, coverage of women, and women's rights," and that "there may be some points on which we disagree" but that "this study reveals that unconsciously we still are doing things and writing things that are simply not in keeping with the consciousness of women as total individuals and of their contribution to society." 100 Comparing this reaction to his pre-emptive discouraging meeting with Caucus members, it appeared that Rosenthal was more open to suggestions from women who were not his employees. There is no evidence that the chapter of NOW reached out to women at the Times before approaching management.

Some Caucus members resented these efforts by NOW and other feminists to bring Times management to task despite never including the women actually employed there. These feelings had echoes throughout the media; when Susan Brownmiller successfully negotiated eight pages of a future Ladies' Home Journal issue to fill with feminist content following her sit-in, the protesters authored the content, not the women reporters already employed at the Journal. ${ }^{101}$ This was despite the fact that the protesters' list of demands had included changes to employment in addition to content (such as "all editorial employees of the magazine be women"). ${ }^{102}$ Wade said the Caucus "did not feel ourselves allied to the rest of the women in the media," and that when NOW contacted the Times or "frequently" held pickets outside the building, "they never called us." She suggested that if they had called, the Caucus members would have been happy to participate in pickets, but that NOW did not think "there were any women inside the New York Times." 103 This claim contradicts statements by Wade and other Times journalists, including Eileen Shanahan, who recalled feeling pressure to distance themselves from the feminist movement in order to maintain their standing at the paper. It is therefore unlikely that the Caucus members would have joined in pickets outside their own employer. However, Wade's comments are representative both of the feminist sentiment that Caucus members felt, even if they were strategic in their expression of it, and of the often fraught relationship between feminist activists who protested specific media outlets and the newswomen who worked at those same media outlets.

Despite the frustration of Caucus members, outside pressure may have assisted in their fight. ${ }^{104}$ In April 1973, Sulzberger wrote to Rosenthal and the rest of his management team alerting them to "increasing pressure from women's groups" to hire women and promote

\footnotetext{
${ }^{99}$ Patricia Bosworth et al. to Sunday women, Nov. 20, 1972, and Open letter to Max Frankel, Jan. 2, 1973, folder 25, box 2, NYTWC.

${ }^{100}$ A. M. Rosenthal to Times editors, undated, folder 18, box 1, NYTWC.

${ }^{101}$ Dow, Watching Women's Liberation, 1970, 102, 115.

102“Demands," undated [1970], folder 10, box 30, Susan Brownmiller Papers, Schlesinger Library, Radcliffe Institute, Harvard University, Cambridge, MA.

${ }^{103}$ Wade interview.

${ }^{104}$ This was not the only example of media employees being assisted by efforts from feminist non-employee activists. For example, NOW used petitions-to-deny license renewals at TV stations to advocate for improved hiring
} 
women, and aligned this pressure with the "indication that Times women may be bringing charges through the Office of Equal Opportunity and possibly the Federal Courts." The solution, as he saw it, was "some additional public commitment in the form of an affirmative action plan." ${ }^{105}$ He later pressed how "crucial" this was "both in terms of our own conception of what is right and in terms of our potential vulnerability to embarrassing and expensive lawsuits."106

The actions of feminist activists outside the Times and the Caucus cannot be easily separated into different feminist traditions or activist groups. Both activists outside the paper and Caucus members were motivated to change the institution out of their concern for women and discrimination. However, while outside feminists were driven primarily by their interest in combatting sexist stereotypes and media portrayals, Caucus members came together around the issue of work. The Caucus's strategic separation from the feminist movement illuminates the different ways women navigated the professional restrictions under which they operated and articulated feminist beliefs without overtly defining them as such.

\section{Transitioning to a Lawsuit}

By July 1973, the Caucus members were fed up with the lack of movement from management and began to streamline their varied approaches into one single goal: a class action lawsuit. They also found the publisher and his management team out of sync in their wishes. At a meeting in December 1972, Rosenthal had met with the Caucus and detailed what the Times saw as accomplishments "in the area of minority representation" since their first meeting in May. These included fourteen raises to individual newswomen, a promotion for Grace Glueck, and three transfers for women to other bureaus. Less encouraging was Rosenthal's claim that "all women on the staff have been given consideration for every opening or transfer," particularly when there was no transparency in the hiring process, and that in spite of this consideration, men had still been promoted into three major positions that had openings. While there was some acquiescence on the issue of promotions and hiring, the Times continued to refute the Caucus's claims about unequal pay. During the meeting, Rosenthal said the news department "did not feel that women's salaries were now that far out of joint with male salaries when factors such as experience, quality of work, etc. were considered." ${ }^{107}$ Yet in January 1973, Sulzberger issued a company-wide memo calling for "equal pay for equal work" and "full use of the talents and training of women employed at the Times." 108

Despite Sulzberger's assurances, Rosenthal's approach epitomized the attitude Caucus members experienced in their meetings with management, and it seemed likely that Sulzberger's supportive memos were merely feel-good press releases, intended to alert the public to the Times's progressive policies, without actually making any changes. Following this inaction, by 1973 Harriet Rabb began organizing the women to file charges with the New York City Commission on Human Rights (NYCC) and the EEOC. ${ }^{109}$ At the same time, the Caucus arranged a permanent base from which to organize and began renting a tiny, lockable room on the ninth floor of the Times building to act as Caucus headquarters. In yet another small indignity, the building management made out the invoices for the office to "Betsy Wade, Women's Libbers." ${ }^{110}$ Even if the Caucus members did not explicitly connect their actions

and working conditions for the women employed there. See Allison Perlman, "Feminists in the Wasteland: The National Organization for Women and Television Reform,” Feminist Media Studies 7, no. 4 (2007): 413-31.

${ }^{105}$ Arthur Ochs Sulzberger to A. M. Rosenthal et al., Apr. 18, 1973, folder 10, box 112, AMRP.

${ }^{106}$ Arthur Ochs Sulzberger to A. M. Rosenthal et al., July 12, 1973, folder 8, box 112, AMRP.

${ }^{107}$ Peter Millones to Arthur Ochs Sulzberger, Dec. 1, 1972, folder 7, box 95, AMRP.

${ }^{108}$ Arthur Ochs Sulzberger to All Employees of The New York Times and Its Subsidiaries, Jan. 11, 1973, folder 17, box 1, NYTWC.

${ }^{109}$ Robertson, The Girls in the Balcony, 163.

${ }^{110}$ Betsy Wade to Richard Rogers, Aug. 5, 1973, folder 17, box 1, NYTWC. 
to the feminist movement, the men within the Times building failed to grasp the distinction. To assist in filing their complaints, Rabb carefully handwrote instructions for what women should write in each section of each form, which Wade and Cook typed up and distributed with batches of forms to different departments in May 1973. ${ }^{111}$ Rabb told Caucus organizers that "the more forms, from the more departments, the better." 112

Even with the swell of support they had received from women across many of the fourteen floors the paper occupied in the Times building, when it came to putting their name on record, Caucus members recall it was a "hard sell," and suddenly "a lot of people were satisfied with their jobs and had wonderful bosses."113 The key group-Betsy Wade, Grace Glueck, and Joan Cook, with help from a constantly rotating cast of women mostly from the newsroom - had sat across from Sulzberger and Rosenthal so many times now that putting a complaint down on paper may have seemed like a minor step. Women without the relationships the Caucus leaders had with management faced more challenges. The Caucus leadership's proximity to their opponents benefitted them; they had long revealed their position to management, and so they had little left to lose by formalizing their complaints. Wade and Cook were also experienced enough with the union to understand that the Guild would protect them from retribution and retaliation from Times management. Luckily, their hard sell worked on enough women. By July, eighty-four women filed discrimination charges with the NYCC and the EEOC. The majority of the complaints copied Rabb's suggested language word for word, but some-including Wade-added their own specific grievances. ${ }^{114}$ In addition to women in the news and Sunday departments, the complainants came from the classified, telephone recording, building cleaning, and personnel benefits departments-and even from the assistants who worked in the office of the managing editor, Rosenthal. ${ }^{115}$

In 1974, the Times attempted to deter the Caucus with a new affirmative action plan, just as the Caucus had requested in their initial 1972 letter, and Sulzberger had suggested in his 1973 panic over potential litigation. Initially optimistic, Rabb called the approach "great news." ${ }^{116}$ By February, the Caucus members' perspectives had become more cynical, and they characterized the plan as "not incidentally" intended "to ward off law suits from complaining groups." 117 In April 1974, the Times announced in the company's internal newsletter, Times Talk, that the plan "rules out discrimination" and aimed to "achieve, within a reasonable period of time, an employe [sic] profile with respect to race and sex in job categories, which is an approximate reflection of proper utilization." ${ }^{118}$ It did not take long for the Caucus members to become dissatisfied with the plan and distance themselves from it. Caucus leadership arranged a meeting of the broader membership at the Guild offices in September 1974, to decide "what steps to take next." They were not coy about what such steps might constitute, noting that "one of our options is having a small group of us institute a court action on behalf of all of us." "119 Internally, Caucus leadership had been discussing this possibility for several months. Following Rabb's failure to get the Times management to make any additional commitment to monitoring the affirmative action plan, she had corresponded with Wade, Glueck, and Cook. By early August, they discussed "the suit" as if the rest of the Caucus had already agreed

\footnotetext{
${ }^{111}$ Negotiating Committee to Times Women, May 23, 1973, folder 32d, box 3, NYTWC.

${ }^{112}$ Betsy Wade to Grace Glueck, May 14, 1973, folder 11, box 1, NYTWC.

${ }^{113}$ Robertson, The Girls in the Balcony, 164.

${ }^{114}$ Robertson, The Girls in the Balcony, 164; Elizabeth Boylan (Betsy Wade), New York City Commission on Human Rights form, undated, folder 24, box 2, NYTWC.

${ }^{115}$ List of women who filed complaints, July 22, 1973, folder 24, box 2, NYTWC.

${ }^{116}$ Grace Glueck to Betsy Wade, Jan. 11, 1974, folder 32c, box 3, NYTWC.

${ }^{117}$ Memo to Times Women, Feb. 1974, folder 32c, box 3, NYTWC.

118“The Times Adopts Affirmative Action that Rules Out Discrimination," Times Talk, Apr. 1974, folder 32c, box 3, NYTWC.

${ }^{119}$ Memo to Times Women, undated, folder 17 , box 1, NYTWC.
} 
to forge ahead. ${ }^{120}$ Finally, in the Guild's meeting room at the Caucus's September meeting, Caucus members voted "overwhelmingly" to take their case to court. ${ }^{121}$

The Caucus spent the remainder of 1974 deliberating over suitable plaintiffs to represent their class in court. Despite their origins as a group of newswomen, Caucus members, following Wade's direction, wanted their suit to encompass all women employed at the Times, rather than just the paper's female reporters. This path had been decided with their 1972 decision to open Caucus membership. Their decision was in contrast to several lawsuits at other media outlets, where newswomen remained the focus. Yet in spite of concerted efforts to broaden membership to women workers from across the Times building, at the time of filing suit in 1974, the majority of members remained reporters. ${ }^{122}$ One major obstacle in recruitment was the existence of the Times Minority Caucus, which organized its own race discrimination lawsuit in conjunction with the Guild and included many of the non-reporters and women of color who the Caucus hoped to recruit. ${ }^{123}$ Having a majority of reporters also meant that the majority of Caucus members were white. In 1968, the Kerner Report found African Americans held fewer than 5 percent of editorial positions in the news business, made up fewer than 1 percent of editors and supervisors, and that "most of them work for Negro-owned organizations." 124 While it is likely that the decision to expand the class to employees of color working outside the newsroom came from genuine ideological beliefs, it was also a legal strategy. In order to ensure their complaint did not appear to be helmed by only white, middle-class, educated professional women, the Caucus needed a diverse array of plaintiffs. ${ }^{125}$

Eventually, in addition to Wade, Glueck, Cook, and Washington, DC journalist Eileen Shanahan, Harriet Rabb identified three more plaintiffs outside of the newsroom to round out their case. Eighth-floor accounts and benefits administration clerk Louise Carini had trained at least six men who had then been promoted above her. At twenty-nine, sixth-floor classified department telephone ad taker Nancy Davis was the youngest of the plaintiffs. She worked in a department considered a "female ghetto" and had unsuccessfully applied for nine jobs since joining the Times in March 1972. Finally, the Caucus recruited one non-white plaintiff: Andrea Skinner, an African American news clerk in the eighth-floor Sunday magazine fashion section who had quietly and successfully diversified the child models used in the paper, but who had only received one merit raise since $1965 .{ }^{126}$ Elizabeth Boylan, et al. v. The New York Times Company, submitted under lead plaintiff Betsy Wade's legal married name, was filed in the Southern District of New York on November 7, 1974. ${ }^{127}$

\footnotetext{
${ }^{120}$ Grace Glueck to Betsy Wade, Aug. 4, 1974, folder 17, box 1, NYTWC.

${ }^{121}$ Robertson, The Girls in the Balcony, 168.

${ }^{122}$ Negotiating Committee to Times Women, Nov. 16, 1972, folder 32b, box 3, NYTWC; Betsy Wade to Grace Glueck and Joan Cook, Aug. 12, 1974, folder 18, box 1, NYTWC.

${ }^{123}$ Turk, Equality on Trial, 56.

${ }^{124}$ National Advisory Commission on Civil Disorders, Report of the National Advisory Commission on Civil Disorders (Washington, DC, 1968), 211. Matthew Pressman argues that the 1960s riots forced white-owned mainstream news media to hire black reporters. Matthew Pressman, On Press: The Liberal Values That Shaped the News (Cambridge, MA, 2018), 152. However, the color line demarcated the white-owned and black-owned press in the twentieth century, and each were staffed along predominantly segregationist lines, with the white press erecting barriers to maintain this segregation. For the discrimination of black journalists by the white press, see Pamela Newkirk, Within the Veil: Black Journalists, White Media (New York, 2000); Donald A. Ritchie, Reporting from Washington: The History of the Washington Press Corps (Oxford, UK, 2005), ch. 2; and Gwyneth Mellinger, Chasing Newsroom Diversity: From Jim Crow to Affirmative Action (Urbana, IL, 2013), ch. 1.

${ }^{125}$ Serena Mayeri has argued that feminists benefitted from the "civil rights revolution" and drew race-sex parallels in order to argue that "similarities between sex and race warranted comparable treatment," a strategy which became a "center-piece of feminist legal advocacy" from the 1960s. Mayeri, Reasoning from Race, 10.

${ }^{126}$ Robertson, The Girls in the Balcony, 168-9, 174-5.

${ }^{127}$ Boylan v. Times, 74 Civ. 4891 (S.D.N.Y. 1978).
} 
From that moment, the lawyers mainly handled the suit, and the Caucus had less to do. The plaintiffs and witnesses stayed in constant contact with Rabb about their depositions and related materials, but the broader Caucus membership could contribute little, although the plaintiffs updated them when they could. ${ }^{128}$ The years of ongoing meetings, debating, and strategizing were over. The process of class certification and discovery took three years, and in 1978 the suit finally approached trial. The lawyers' negotiations in the lead up to the proposed trial date reinforced what both sides had begun to believe: that, in the words of Times lawyer Katharine Darrow, a trial would be "worse than a divorce." 29 Although Times managers held out until the end, with a trial date set for September 28, 1978, the paper's owner finally gave his lawyers approval to begin settlement negotiations. ${ }^{130}$

Caucus members felt an anticlimax with the final settlement, and the plaintiffs were highly divided over whether to accept it or to take the Times to court. Despite the Caucus's democratic origins, the records contain no discussion of letting the broader membership vote. Eventually the plaintiffs accepted the offer: an affirmative action plan that set out hiring goals for women across departments and a total of $\$ 350,000$. Of this money, $\$ 1,500$ was granted to the Caucus for the cost of monitoring the affirmative action plan, $\$ 15,000$ was distributed among the named plaintiffs and witnesses, and a further $\$ 233,500$ was distributed among all members of the class on a sliding scale based on years of employment as an annuity. The highest amount a single member of the class could get out of the settlement was $\$ 2,000$, which was awarded to Betsy Wade for her years of trouble. ${ }^{131}$ Although Wade was already on a comfortably high salary, for most Times women, the settlement certainly did not go far in addressing the now $\$ 5,160$ average yearly wage gap. ${ }^{132}$

In favor of the settlement, Rabb reportedly told the plaintiffs: "This is the best offer we are going to get," even though many of them found the terms unsatisfactory, particularly because they did not include an admission of guilt. Rabb herself received no payment from the settlement, although Columbia Law School received $\$ 100,000$ out of the total for training programs including the Employment Rights Project, which had helped Rabb manage the lawsuit pro bono. A Times spokesperson claimed the settlement was "total vindication of the New York Times and ... full refutation of the charges against us." ${ }^{133}$ The magistrate overseeing the case said, "I think it would be a mistake if one reached a conclusion that there was a victory.". Wade's summary was similarly restrained: "I think the Times lost a lot. I don't think we won a great deal."135

\section{Conclusion}

The day-to-day reality of the Caucus makes stark what historian Nancy MacLean has noted: "Title VII may have promised a new order, but there was no blueprint." ${ }^{36}$ Many women may have formed caucuses, filed with the EEOC, and armed themselves with legal definitions and assistance, but no guaranteed path for winning yet existed. A great deal of day-to-day work

\footnotetext{
${ }^{128}$ Notice to Times Women, Oct. 12, 1976, folder 3, box 1, NYTWC.

${ }^{129}$ Robertson, The Girls in the Balcony, 202.

${ }^{130}$ Robertson reported that Times Executive Vice President James C. Goodale refused to settle (The Girls in the Balcony, 204), while Caucus member Eileen Shanahan claimed instead that it was Rosenthal, who was finally brought in "kicking and screaming" to negotiate after an order from the judge. Eileen Shanahan interview by Mary Marshall Clark, 1992-1994, transcript, Washington Press Club Foundation Women in Journalism Oral History Project, Washington, DC. Harriet Rabb to Witness, Sep. 22, 1978, folder 2, box 1, NYTWC.

${ }^{131}$ Povich, The Good Girls Revolt, 157.

${ }^{132}$ Robertson, The Girls in the Balcony, 181.

${ }^{133}$ James C. Goodale statement, Oct. 6, 1978, folder 32h, box 3, NYTWC.

${ }^{134}$ Robertson, The Girls in the Balcony, 208.

${ }^{135}$ Wade interview.

${ }^{136}$ MacLean, Freedom Is Not Enough, 9.
} 
undergirded a discrimination lawsuit, as well as an ongoing struggle at a workplace where the plaintiffs continued to be employed. Not only did Wade, Glueck, Cook, and the other Caucus members have to write their newsletter, post notices of meetings, negotiate with management, correspond with their lawyers, and run to the Guild offices for fact-finding and meetings, they also had to put out a newspaper every day.

In addition to their grassroots workplace organizing, newswomen in the 1970s advocated for greater coverage of the feminist movement, often by incorporating the new beat into their workload for no extra pay. They did so while navigating the professional requirements imposed by their employers, which asked them to distance themselves from the feminist movement in order to retain their "objectivity." As Matthew Pressman has noted, "Powerful, established institutions generally reflect and reinforce the dominant attitudes of the broader culture." 137 The search for "objectivity" or "balance" in journalism meant enshrining those voices who the journalistic establishment believed to represent the norm, leading many reporters to equate "objectivity" with maleness and whiteness. Newswomen's reporting on the feminist movement and their involvement in feminist workplace organizing fed into one another, and the interaction between these two experiences inspired a process of consciousness-raising among newswomen, which in turn fed back into their reporting and their activism. Caucus members were feminist actors in their own right, but actors not wholly part of the feminist campaigns around the media. Their activism also intersected with, and was informed by, some background in labor organizing. As such, they deserve the label "labor feminists": although they experienced class and race advantages compared with other women working throughout the Times buildingor women in many other professions-they wielded very little power in their own workplace.

Although the settlement may not have been the landmark change that the Caucus had initially envisioned over lunch at Act One, their actions had broader implications. To be sure, at an event celebrating the ten-year anniversary of their settlement, women employed at the Times noted that while things had improved, they still received thousands of dollars a year less than their male counterparts. Eileen Shanahan told them: "I have a feeling you ought to sue the bastards again." ${ }^{138}$ Still, in the years immediately following the lawsuit, the Times did hire a series of women who rose through the paper's ranks. The very existence of a monitored affirmative action plan constituted a formidable challenge to the previous system, in which men saw nothing wrong with having an all-female classified department or restricting women from certain positions. ${ }^{139}$ Wade and her fellow plaintiffs may have exerted a huge amount of effort in order to reap very few rewards personally, and the Times women who followed them still had a lot of work ahead, yet the charge of discrimination at a paper held up as a symbol of liberal politics was groundbreaking for women across the U.S., and it provided a guiding model for other caucus and media discrimination complaints that followed. To women outside of the Times, the contribution was clear. ${ }^{140}$

Indeed, the 1970s saw the politicization of a generation of newswomen. Their work altered the trajectory of reporting at their individual news outlets long after their specific activist campaigns ended. Collectively, these individual contributions assisted in the gradual transformation of the news media throughout the 1970s, and indeed, the place of women in modern U.S. society. ${ }^{141}$ While not all stories about the feminist movement were authored by women, and not all women who reported these stories were involved in grassroots workplace activism, newswomen

\footnotetext{
${ }^{137}$ Pressman, On Press, 149.

${ }^{138}$ Women's Caucus 10th anniversary of settlement transcript, Oct. 18, 1988, folder 90-M208, box 1, NYTWC supplementary material (76.3.1).

${ }^{139}$ MacLean, "The Hidden History of Affirmative Action," 46.

${ }^{140}$ Wade interview.

${ }^{141}$ This is not to overstate the contributions of individual newswomen. As sociologist Kaitlynn Mendes has argued, newswomen authored "only a fraction of the articles published [on feminism]" in the 1970s, which is not surprising given that men continued to overwhelmingly dominate newsrooms, and some women avoided
} 
over many years kept up the pressure to shift reporting and to hire and promote women. And as key actors in these changes, Times Caucus members were influential feminist actors during the 1970s. Their presence challenged the default white male perspective inbuilt in media institutions. Infused by feminist protests and ideology, they experimented with tactics adopted from the labor and union movements, and did not commit to a single ideology. They directly challenged a media institution often held up as a model of objectivity and contributed to the feminist movement meaningfully and significantly.

Marama Whyte is a research associate in the Department of History at the University of Melbourne, Australia. Her work sits at the intersection of feminist, labor, and media histories. She is currently working on her first book, which examines grassroots feminist activism by women journalists employed in the mainstream U.S. media during the 1970 s.

writing about the movement for professional and strategic reasons. Kaitlynn Mendes, Feminism in the News: Representations of the Women's Movement Since the 1960s (Hampshire, UK, 2011), 165. 